\title{
Media and the message
}

UPNG's journalism program has performed with distinction since it began in 1975 with New Zealand Government aid funding the staff and courses for about three years. More than 170 students have graduated with degrees or diplomas in journalism and the university's alumni are today found in key media positions or civil life throughout the Pacific.

\section{By DAVID ROBIE}

IZZY STONE, the doyen of American modern muckrakers, once said before he died in 1989: 'An independent journalist always has to be willing to offend his following.' In this age of media buyouts, corporate monopolies, consensus news, infotainment, tabloid journalism and 'feel good' journalism, the example set by Stone's life remains an inspiration.

Early in his career as an investigative journalist, Stone exposed the US Atomic Energy Commission's web of lies about the safety of underground nuclear testing. In the mid-1960s, he laid bare the truth about an invented attack on American warships that provided the excuse for President Lyndon Johnson to escalate the war in Vietnam.

But he is perhaps remembered best for his own newspaper, I. F. Stone's Weekly, which was one of Washington's most feared and most influential publications.

No doubt, if Izzy Stone was still around today he would have backed recent comments about the media in Papua New Guinea by corruption buster Frank Costigan, Transparency International PNG Inc chairman Sir Anthony Siagaru and others. Costigan, a Queen's Counsel who headed the inquiry into the Australian dockland corruption in the 1980s, argues for the need for publicity, analysis and pressure to expose the corrupt. He told a recent seminar on integrity that some of the vital ingredients for this were an independent and diverse media, an effective parliamentary opposition, the Auditor-General's office, the courts and an independent legal profession.

Of all these factors, conceded Costigan, the media was perhaps the most important. 'Corruption cannot persist in the sunlight of exposure - it needs the 


\section{JOURNALISM EDUCATION AT UPNG From previous page} came to nothing, however, and in 1983 and 1984 UPNG undertook internal reorganisation to make it possible to employ a second lecturer in journalism, and advertised the position.

At the beginning of 1985, the two-year Diploma in Media Studies was offered for the first time, and the first students graduated at the end of 1986. The four-year Bachelor of Journalism degree program was offered for the first time in 1986, to students who had already successfully completed the university's general foundation year. The first students [graduated] with this qualification at the end of 1988 .

The late Peter Henshall wrote this commentary as part of a paper, 'Journalism Education and Training at the University of Papua New Guinea', published in Pacific Islands Communications Journal, 15:2, 1988, pp 32-39.

shade and the closed doors and the secrecy,' he said.

In May 1997, Sir Anthony appealed at a seminar organised by the Ombudsman Commission for the media to educate the people and encourage them to become 'a nation of whistleblowers' to curb the corruption that has become 'endemic'.

In the wake of the Sandline mercenary affair, these are all noble and popular sentiments echoed by many community leaders and leading politicians anxious to sign the national integrity pledge. But little thought is given to how the media actually fulfills this serious responsibility.

Both the national dailies and weeklies, and EM TV (in particular John Eggins with his documentary The Ultimate Test) have performed creditably with some robust journalism and excellent in-depth reports. Yet quality journalists don't just suddenly materialise. They are the product of sound training and a broad liberal education in their formative years, honed by experience in competitive and diverse media organisations.

The Papua New Guinea news media has been well-served by the education system - according to recent research some 68 per cent of PNG journalists have a university or tertiary qualification. ${ }^{1}$ This is far higher than Fiji (16 per cent, although this should climb rapidly with the new journalism school at the University of the South Pacific) and slightly higher than Queensland.

A generation of journalists have been educated since independence at the University of Papua New Guinea and more recently at the Divine Word University (formerly Institute). In this era of mass-oriented, depersonalised and conformist type of global journalism, there is a vital need for critical, thinking 
MEDIA AND THE MESSAGE

and ethically aware journalists. According to Professor John Merrill, of the University of Missouri's Journalism School, who wrote the classic Existential Journalism:

\begin{abstract}
What we need is more emphasis on the individual journalist, on personal freedom and personal responsibility.

In the last several decades we have paid enough attention to the journalistic system, to the mass media, and to the media owners and managers themselves. We seem overly concerned about the media retaining freedom from government or from other outside forces, but we rarely focus on the individual journalist who has become hardly more than a robotised functionary of increasingly corporate journalism...

Most journalists will continue to sail placidly on in their comfortable, safe, lifeless, nonexistential worlds, conforming and doing the same old things in virtually the same old ways - with ever improving technology to distract them. Only a few hearty souls will experience the exhilarating spirit of existential journalism. ${ }^{2}$
\end{abstract}

In Papua New Guinea, freedom of the press is specifically provided for in the national Constitution like all other rights and freedoms. As former Ombudsman Sir Charles Maino once said when challenging PNG's journalists: 'Please do not abuse this freedom which is your tool.' ${ }^{3}$ The responsibility of UPNG in producing well-educated and ethical journalists to participate in national development is considerable. The country desperately needs well-qualified, probing, well-informed and courageous journalists to play their role as the 'Fourth Estate' in the democratic process.

UPNG's journalism program has performed with distinction since it began in 1975 with New Zealand Government aid funding the staff and courses for about three years. Among early educators were Michael King, who later became one of New Zealand's finest author-historians, and the late Ross Stevens, who founded the program and died in July 1997 as one of New Zealand's leading current affairs television journalists. ${ }^{4}$

Since the program began, more than 170 students have graduated with degrees or diplomas in journalism and the university's alumni are today found in key media positions or civil life from the Cook Islands to Vanuatu, as well as providing the editors of two of Papua New Guinea's national newspapers and many others in prominent positions in the country today. Its achievements include hosting the PACJOURN project, a UNESCO-funded media training scheme in the late 1980s; being involved in the organisation of the South Pacific Games in 1992; and winning double awards in 1995 for Uni Tavur, the 23-yearold journalism training newspaper which was relaunched that year as a tabloid. 


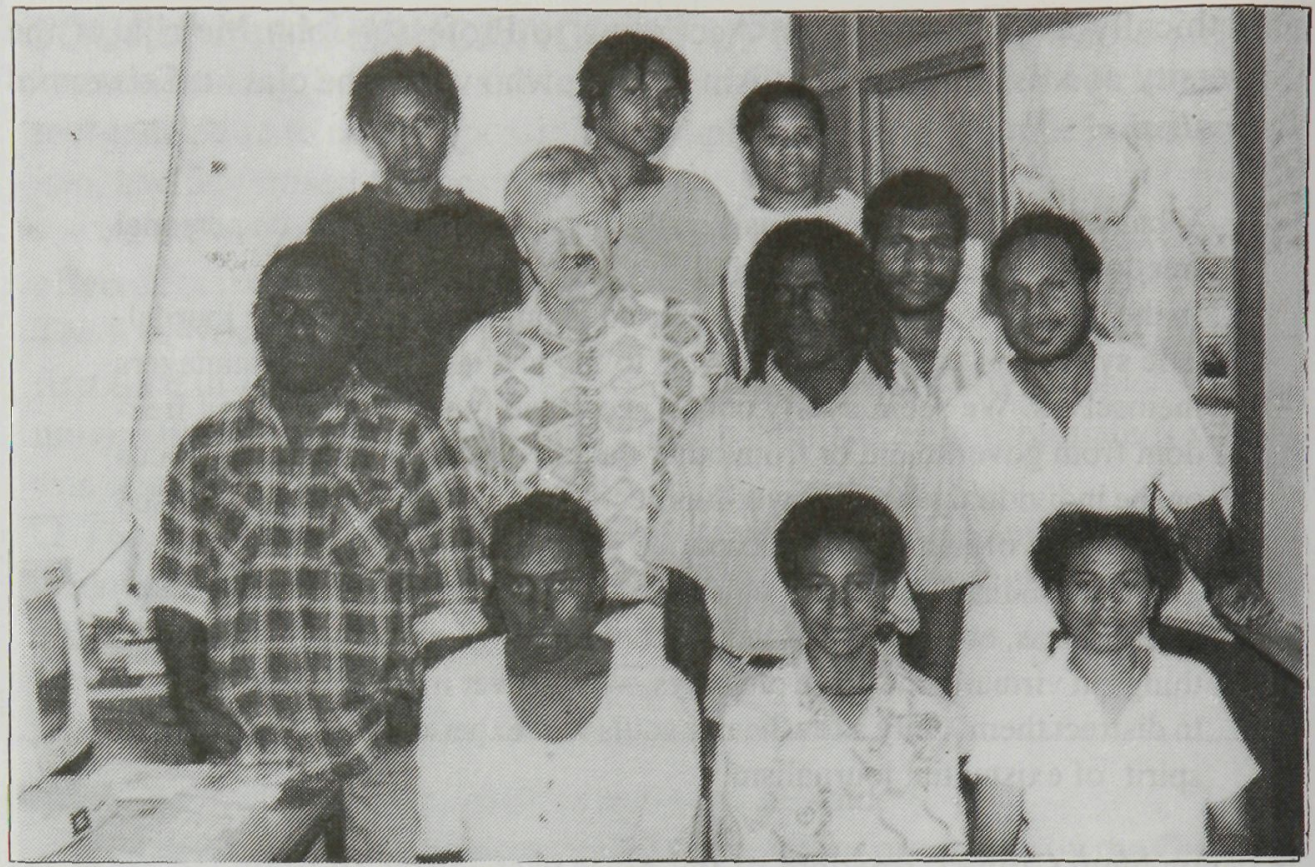

The Uni Tavur editorial production team with their lecturer David Robie in the newspaper's newsroom.

Photo: UNI TAVUR

However, at times it has been treated as a 'Cinderella' by the university for perplexing reasons. During its two decades of existence it has never been provided with the sort of basic broadcast and print facilities one would expect of any journalism school in the world. Journalism is not taught in a conventional classroom - it needs professional newsrooms (preferably with a regular training newspaper), computers, recording studios and equipment (preferably a campus radio station), tape recorders, recording booths, video cameras, editing suites, telephones and fax machines.

When I first arrived at UPNG at the beginning of 1993, although the program was then 18 years old, students were writing in long hand with an abandoned pile of rusting typewriters. The students had not even been provided with a newsroom or a telephone. How could they be educated in how to become a journalist when they are not provided with the basic tools?

How would Physics fare without physics laboratories? Or Chemistry?

The university has a responsibility to provide professional facilities. Compare UPNG with the University of the South Pacific which began a journalism degree program in 1992 with French Government funding totalling $\$ 60,000$ and a media centre. More funding is being allocated this year and the French government will also fund a third lecturer, recruited from Australia.

However, USP has fewer students than the current 48 (in 1993 this figure 100 PACIFIC JOURNALISM REVIEW 1997 
was more than 70 but enrolments have been cut back) enrolled in journalism and public relations courses at UPNG. In the past five years, UPNG's Journalism Studies has been fortunate in gaining grants and donations of equipment and courses totalling about K71,000 which has enabled the setting up of a good desktop publishing newsroom and Internet publishing network. But our broadcast facilities need a major - and expensive upgrade.

The Post-Courier has been one of the key donors, providing K15,000 worth of computers over three years, and printing the popular training newspaper Uni Tavur. Others include the Dutch Communication Assistance Foundation (CAF), Cuso-Canada Fund and the NZ High Commission.

The neglect of the UPNG administration was reflected in a statement by former Acting Vice-Chancellor Nick Kuman who replied in 1995 to journalism students petitioning over the lack of broadcast facilities:

With regard to the funding of the Journalism program, you'll recall that it started off as a temporary course funded externally.

While budgetary provisions have been made, it is up to the government to provide funding for the development of journalism according to its own priorities.

I am fully in support of our ambitious efforts to build up the South Pacific Centre for Communication and Information in Development (especially journalism) as a 'centre of excellence' in the region but we have to be mindful of the fact that we need government support for this. ${ }^{5}$

The hands-off-no-help approach has continued under the present administration to the detriment of the journalism program. Vice-Chancellor Dr Rodney Hills told journalism students late in May in a response to their third protest petition in five years: 'I have noted the main points in your letter and note that they are not new - some of them appear in the 1995 petition.' ${ }^{6}$ Dr Hills' response to Journalism contrasted with his immediate and positive response to law students who also petitioned the Vice-Chancellor about staff problems.

At the time of writing this article I am the sole fulltime journalism lecturer (my colleague Sorariba Nash is on study leave at University of Wales). Administrative expediency has kept it that way. Until 1992, three fulltime journalism lecturers were the norm.

Lack of staff has forced us to cancel this year's postgraduate Certificate in Investigative Journalism and several of our undergraduate courses as well. Uni Tavur has been suspended until next February. ${ }^{7}$

In addition, there are misguided moves, driven by the Library and Information Studies half of SPCenCIID, to absorb the journalism program as part of the major university restructuring exercise into a bland catch-all batch of courses 


\section{DAVID ROBIE}

known as the Integrated Program in Information and Communication Sciences (IPICS).

Journalism is not just 'information' in an unfocused sense - it is a professional career based on the responsibilities and role of the 'Fourth Estate' in a democracy. The IPICS concept fails to acknowledge this fundamental difference. The 'exemplary approach' and 'problem-based' approach to learning characterises the journalism program at UPNG, as in similar successful programs abroad. The concept is to stimulate or create a real working environment for the students who are asked to perform exemplary tasks and to seek solutions to exemplary problems (ie publication of Uni Tavur). ${ }^{8}$

While information science involves passive hoarding or tapping of information, journalism is seeking to fulfil the public's right to know. In fact, journalism has more in common with the media arts (filmmaking, television and photography) strand of courses at the Faculty of Creative Arts.

'As budget-conscious university administrators look for ways to consolidate programs and save money, they too often look for a convenient way to lump everything from journalism to speech pathology under one roof,' says consultant Betty Medsger, who compiled a report on the future of journalism education for the Freedom Forum Media Studies Centre. ${ }^{9}$

Let's not pretend that it is all journalism or that all resources devoted to things besides journalistic core values are helping to prepare future journalists.

To have any hope of taking their place as Papua New Guinea's journalists of the future - let alone investigating corruption or other serious issues - the journalism students of today need core media courses along with a broad liberal arts education. Preparing for a complex multimedia world, the focus should be on students and how to educate them to be critical thinkers, preparing them for meaningful journalism careers and to provide information for the development of the nation.

\section{Notes:}

${ }^{1}$ Layton, Suzanna (1995). "The demographics of diversity: profile of Pacific Island journalists", Australian Studies in Journalism, Vol 4, No 1, p 137.

${ }^{2}$ Merrill, John (1977, 1996). Existential Journalist. Ames, Iowa: Iowa State University Press, pp 7-8.

${ }^{3}$ Maino, Sir Charles (1995). 'People, news and government', Pacific Journalism Review, 2:1, p 86.

4 Avi, Kenneth Ua (1997), 'UPNG journalism program mourns the loss of Ross Stevens', Media Nius, 1:2, August. 
${ }^{5}$ Kuman, Nicholas (1995), Acting Vice-Chancellor of UPNG. Memorandum to the journalism lecturers regarding delays in making the Education Faculty room available for conversion into a Newsroom and facilities, August 14.

${ }^{6}$ Hills, Dr Rodney (1997), Vice-Chancellor of UPNG. Letter to the President of the Journalism Students Society, Jean Yapog, in reply to their April 30 petition asking the administration to ' 1 . [provide] two more lecturers as soon as possible [restoring the number to three]; 2 . fund the journalism electronic program with necessary facilities, especially the defunct broadcast studio, with a digital one; 3 . fund the journalism [publishing] program; and 4. separate Journalism Studies from Library and Information Studies. May 13.

'An 'extra' special edition of Uni Tavur was published on 14 October 1997 which contained a four-page liftout Insight Report on the future of the newspaper and the journalism program.

${ }^{8}$ Robie, David (1997). 'Journalism Restructuring Profile', Proposed School of Humanities and Creative Arts, UPNG, p 2.

${ }^{9}$ Medsger, Betty, (1996). Journalism: Winds of Change. New York: Freedom Forum Media Studies Centre.

$\square$ David Robie is Lecturer in Journalism at the University of Papua New Guinea and coordinates the mass communication program. This article was originally published in the Post-Courier on 14 July 1997.

\section{Sudent, community and international journalism education group views on this issue See Forum page 154}

